\title{
ANALYSIS AND SYNTHESIS OF SILHOUETTES OF FRONTAL - AND FLANK-ATTACKING SHOOTING TARGETS USING GRAPHS
}

\author{
Vadim L. Khaikov \\ independent researcher, Krasnodar, Russian Federation, \\ e-mail: wadimhaikow@inbox.ru, \\ ORCID iD: (Dhttp://orcid.org/0000-0003-1433-3562
}

DOI: 10.5937/vojtehg67-21754; https://doi.org/10.5937/vojtehg67-21754

FIELD: Applied Mathematics (Ballistics, Theory of Shooting)

ARTICLE TYPE: Original Scientific Paper ARTICLE LANGUAGE: English

Abstract:

The goal of this contribution is to reveal the analytical framework and synthesis guidelines for frontal-attacking targets (FRATs) and flankattacking targets (FLATS) from the point of view of a graph as a mathematical object. The final outcome of this study are three graph models that in many ways describe the shooting targets under consideration. The first graph model characterizes the structure of connections between the vertices using an undirected graph. The model showed that the complexity of silhouettes leads to an increase of the path in the graph and growth of the complexity of its internal structure. The second graph model allows the analysis of the connectivity of the graph vertices. In this case, a bipartite graph is used. As a result, the reviewed FRATs and FLATs are described by the same graph. The second model showed its indifference to the types of the used graphic primitives (GPS). The third graph model was developed for the analysis of the common borders of the neighboring GPs and it uses a bipartite graph. It is also indifferent to the types of the used GPs, but it takes into account the length of the common borders. The third model describes FRATs/FLATs groups in the same way. When using I-III models, one can design GPs and carry out the synthesis of new targets. A full group of flank-attacking targets consisting of five silhouettes and their GPs is offered.

Key words: shooting target, geometric primitive, graph, adjacency matrix, Mathcad. 


\section{Introduction}

The availability of various shooting targets in training processes makes it possible to reproduce necessary combat situations for operators of military special operations units as well as for radio-operators of robotized ground combat systems with remote operating control. Since shooting at selected targets is carried out only after the detection, classification and aiming stages, the process of developing a mathematical description of human-like silhouettes is actually a scientific field.

Despite a diversity of plane shooting targets (PSTs), target design as a generation of combatants' silhouettes is not widespread in scientific literature. A generally accepted point of view is that it is a phenomenon of human creativity which has a complex formal description.

Graphs are widely used for modeling different processes in physics, chemistry, engineering, information systems (Bondy \& Murty, 1982), (Kennedy \& Quintas, 1988), (Xu, 2003), and for image processing (Lézoray \& Grady, 2012). Military applications also often apply the graph theory in: military geography and geodesy (Talevski \& Temjanovski, 2003), military planning systems (Boukhtouta et al, 2011), (Hocker, 2012), and combat modeling (Tolk, 2012).

Based on the graph theory in (Khaikov, 2019), there is a description of a geometric similarity between the silhouettes of PSTs used in the Swiss Confederation (Wikipedia Contributors, 2012) and in the USSR/Collective Security Treaty Organization (Tarchishnikov, 2011). However, the considered two groups of PSTs belonged to the same target type, namely to frontal-attacking silhouettes. This study is a continuation of the previous paper (Khaikov, 2019). This new contribution attempts to widen the methods of the graph theory for the analysis of frontal-attacking shooting targets (FRATs) to flank-attacking shooting targets (FLATs). The goal of this work is to determine the principles of construction, analysis and synthesis of the methods for the FRAT/FLAT geometry from the point of view of a graph as the prime object of discrete mathematics. The computer algebra system Mathcad is used for graphic visualization of these sets of problems.

\section{Description of a single PST and a group of PSTs in terms of graphs}

Depending on the direction of displacement relative to an observer, an infantryman can move forward/backward and from left to right (or vice 
versa). On the other hand, regardless of the direction of movement, an observer can see only a head of an infantryman, a head and a chest together or a full-size figure. If a real human silhouette is replaced by a set of abstract shapes, then this group of targets must be controled by some discretely variable parameter. The total area of a human-like silhouette visible to an observer can be recognized as such. Therefore, if the direction of an infantryman's displacement is considered as a classification criterion, and if an independent observer sees only a certain part of an infantryman's silhouette, one can create frontal-attacking and flank-attacking shooting targets.

In Fig. 1, we consider five Soviet/Russian FRATs and two (outside of the rectangle) FLATs (Tarchishnikov, 2011). The target geometry will be useful for deeper understanding and further reasoning.
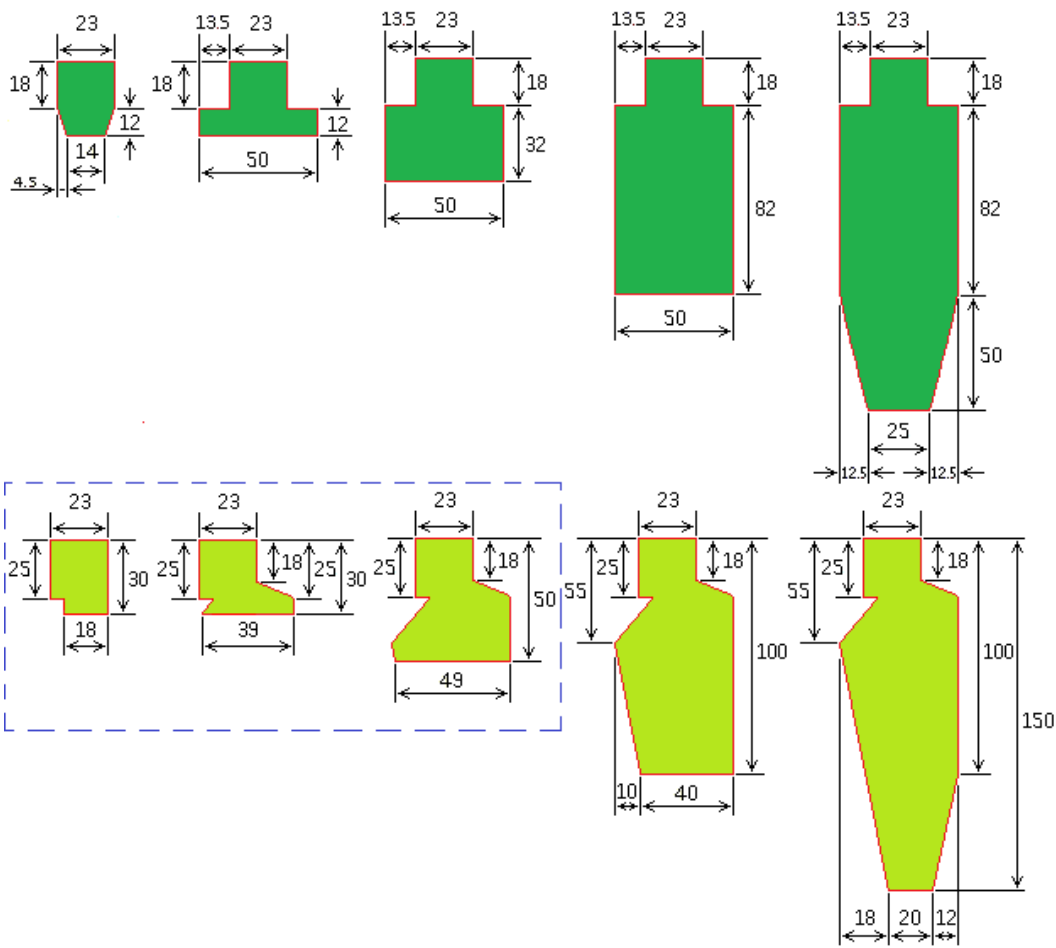

Figure 1 - Silhouettes of five FRATs (top row) and five FLATs (bottom row) Рuc. 1 - Силуэты пяти фрронтально атакующих (верхний ряд) и фрланговоатакующих плоских мищеней (нижний ряд)

Слика 1 - Силуете пет фрронталних мета за гађање (горњи ред) и пет бочних мета за гађање (доњи ред) 
The dimensions of all silhouettes shown in Fig. 1 are given in centimeters. Three figures in the bottom row are drawn inside a rectangle (its perimeter is depicted by a dotted line). It should be mentioned that these images are missing in (Tarchishnikov, 2011) and that they are the result of a synthesis process conducted using I-III graph models, developed below.

Five FRATs have the following designations (from left to right): the head target; the head and shoulders target; the upper torso target; the torso target; and full-sized target. The designations of the two FLATs are: the side view of the torso target; the man-sized target (side view). All FLATs move from right to left. If the movement is carried out from left to right, the targets of the lower row must be rotated horizontally.

Plane shooting targets consist of geometrical primitives (GPs) which are plane figures of elementary shapes. In addition, a single GP can be represented as a polygon. An important feature of GPs is the fact that a PST is built from them like a mosaic. The area of two contiguous GPs increases due to the existence of a common border between them.

Each PST from the FRAT group can consist of a maximum of five GPs (Fig. 2 a). There are "head», "shoulders (left / right)», «bottom of the chest», "bottom of the torso», and «legs» GPs. The minimum number of primitives required to generate a target's shape is one.

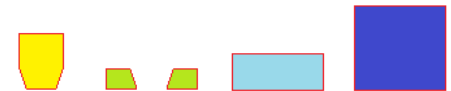

a)

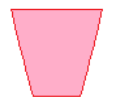

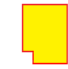

Figure 2-Geometric primitives as constituent elements of PSTs

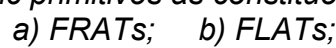

Puс. 2 - Геометрические примитивы как составляющие элементы

а) фрронтально атакующих мишеней; б) фрлангово-атакующих мишеней;

Слика 2 - Основне геометријске фигуре као конститутивни елементи

а) фронталних мета за гађање, б) бочних мета за гађање

The GPs of the FRAT group are obtained by overlaying a GP shape with a smaller area on a shape with a larger area. For example, if the silhouette "the torso target» is placed over the silhouette "full-sized target», we obtain the GP named "the leg». Further, if the "the upper torso target» silhouette is put on the «the torso target» silhouette, one can obtain the GP with the designation «the bottom of the torso», and so on.

Applying the principle of splitting the silhouette for the FLAT group, five GPs were obtained (Fig. 2 b). There are side projections for «the 
head», «the chest / the back», «the bottom of the chest», «the bottom of the torso», and "the leg». The GPs forming the FLAT group do not have axial symmetry; however, the GPs of the FRAT group are symmetric by the vertical OY axis. It should be noted that the shapes of the GPs for the FLATs are more complex than the GPs for the FRATs. In order to compare them more easily, the GPs for the FRATs and the FLATs groups have the same numbers (1-5 from left to right) and identical colors (Fig. 2). The GPs with number 2 for the FRATs and the FLATs groups consist of two areas (light green color).

\section{The first graph-model}

The vertices of the first graph-model (Fig. 3, 4) are geometric primitives and the edges of the graph are the connecting lines between the adjacent GPs. The designations «No. I-V» shows the number of the graph in the group of 6-, 10-, 10-, 12-, 14-vertex graphs.
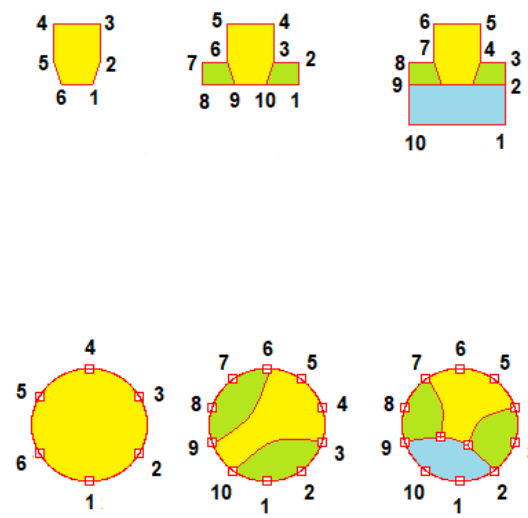

No. I
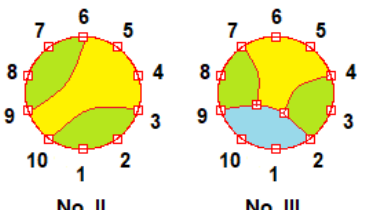
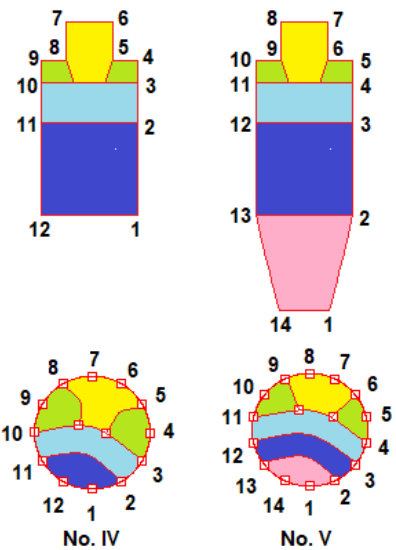

Figure 3 - The graphic visualization of the first graph model for five (I-V) frontal-attacking plane shooting targets

Pис. 3 - Реализация первой графр-модели для пяти (I-V) фрронтально атакующих плоских стрелковых мишеней

Слика 3 - Графички приказ првог модела графра за пет (I-V) фрронталних дводимензионалних мета за гађање

The graph with No. I is a classical circle graph. The vertices of the polygon are numbered counterclockwise. The starting vertex is at the bottom right. The vertices of the graph are not only the vertices of the external polygon (vertices 1-8 for No.2), but also the points of the sides formed by the intersections of the vertices which belong to different GPs (points 9, 10 for No.2). 

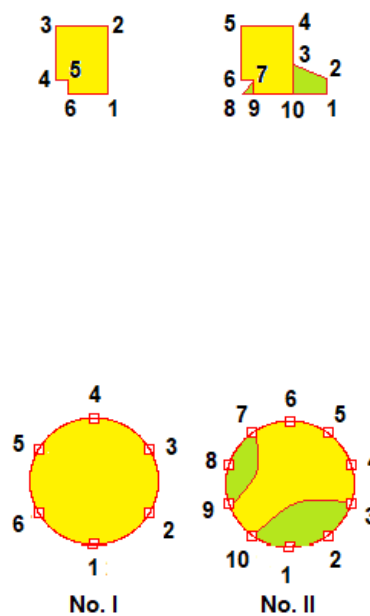

No. II
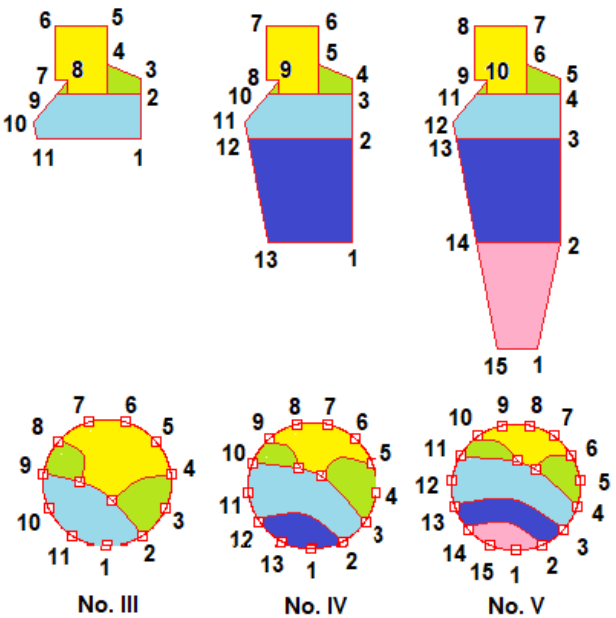

Figure 4 - The graphic visualization of the first graph model for five (I-V) flank-attacking plane shooting targets

Puc. 4 - Реализация первой графр-модели для пяти (I-V) фрлангово-атакующих плоских стрелковых мишеней

Слика 4 - Графрички приказ првог модела графра за пет (I-V) бочних дводимензионалних мета за гађање

The idea of analyzing the graph structure is to isolate the external contour as a set of interconnected vertices and to transform them into a circle. Regardless of the size of the target area in a group, the area of the circle for all graphs is constant (Fig. 3, 4, I-V graphs). Then any connection between the vertices of the external contour can be represented as one or more edges inside the circle. The number of such edges will characterize the complexity of the graph adjacency matrix. The colors of the areas correspond to the colors of the geometric primitives which form a group of targets. In Figures 3 and 4, the ratio of the areas between the geometric primitives that make up the plane shooting targets is not preserved.

A disappearance of target symmetry is detected when an odd number of vertices appears in a circle-graph. In Fig. 3, each of the five circle-graphs has an even number of vertices, i.e. 6, 10,10,12, and 14. By comparing the areas with the same color (Fig. 4), we can notice an unequal number of vertices in the adjacent areas inside the circle. The light green areas of the graphs with III-V number (Fig. 3) have the same number of vertices, but by transition to Fig. 4 , these ratios change. 
In this way, the undirected circle-graph with a constant area has provided a study of the internal connections in both silhouettes: a single PST as well as a group of PSTs.

\section{The second graph-model}

Although the second model was already formulated in (Khaikov, 2019), its application here contributes to the FRATs/FLATs comparison. The second graph-model consists of 10 vertices and 15 edges (Fig. 5).

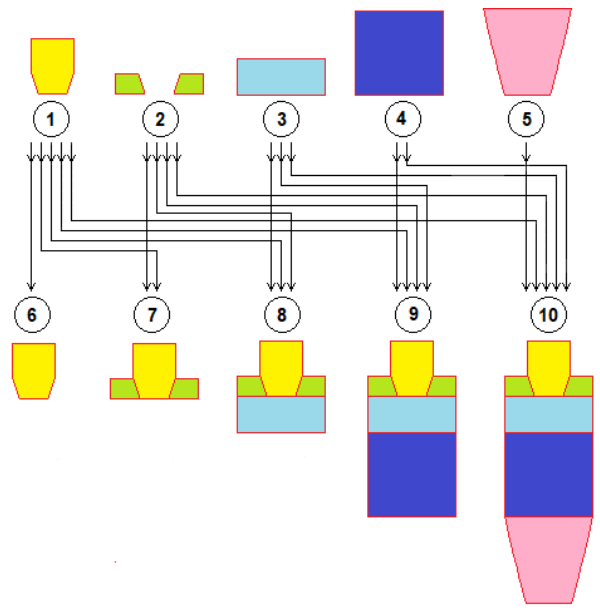

a)

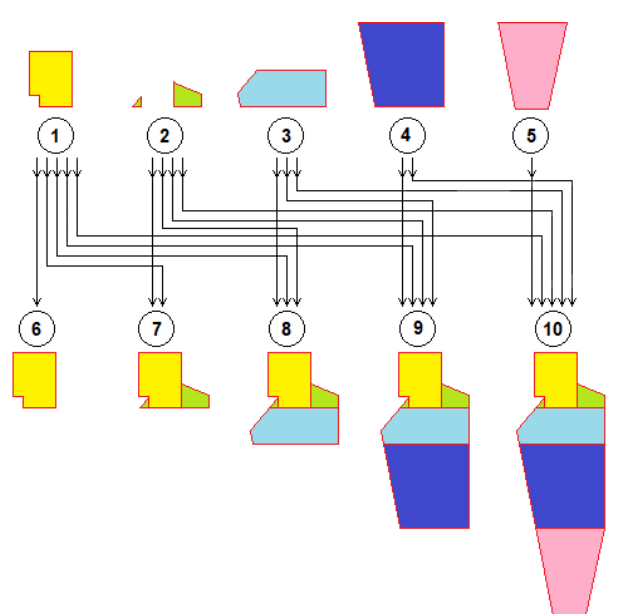

b)

Figure 5 - Target design system for the FRATs (a) and the FLATs (b) groups Pис. 5 - Две системы построения мишеней: а) фронтально атакующих мишеней; б) флангово-атакующих мишеней

Слика 5 - Систем пројектовања мета за групе фронталних (а) и бочних (б) мета за гађање

Vertices numbered 1-5 are GPs. Numbers 6-10 are the vertices of the graph characterizing one of the frontal-attacking (or flank-attacking) targets. The arrows (edges of the graph) show the relationship between the GPs and the silhouettes. The colors of the graphic primitives (the vertices of the graph) are identical to the colors in Fig. 2. The two structures in Fig. 5 represent a target design system (TDS) (Khaikov, 2019). The left TDS (Fig. 5 a) is that of the FRATs group, while the system on the right (Fig. 5 b) can be used for FLAT group generation. Let us draw attention to the fact that the structures of the FRAT/FLAT schemes (Fig. 5 a, b) are the same. The difference is only in the sets of 
the used primitives which are assigned in advance. By rebuilding these schemes, we obtain a bipartite graph (Fig. 6 a)

$$
G_{2}=(V, E)=(10,15)
$$

where $|V|$ - number of vertices (or nodes) (graph order);

$|E|$ - number of edges (links, arcs) (graph size).

In a directed bipartite graph (Fig. 6), the edges are classically drawn as arrows that indicate the direction. The $\mathrm{G}_{2}$ graph does not have loops and multiple edges.

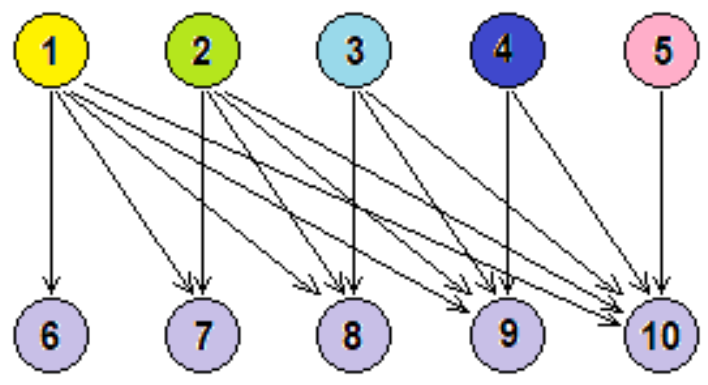

a)

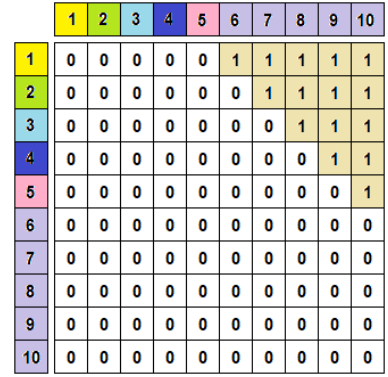

b)

Figure 6 - The bipartite graph of FRATs/FLATs groups (a) and its adjacency matrix (b)

Puc. 6 - Двудольный графр (биграф) фронтально / фрлангово-атакующих мишеней (а) и их матрица связи (б)

Слика 6 - Бипартитан графр група фрронталних и бочних мета за гађање (а) и његова матрица повезаности (б)

For the bipartite graph $G_{2}=\left(V\left(G_{2}\right), E\left(G_{2}\right)\right)$ and the vertex $\left(x_{1}, x_{2}, x_{3}\right.$, $\left.x_{4}, x_{5}\right) \in V\left(G_{2}\right)$, the out-degree of any vertex from the set $\left(x_{1}, x_{2}, x_{3}, x_{4}, x_{5}\right)$ refers to the number of edges-arrows directed away from the selected vertex. The in-degree of $\left(x_{6}, x_{7}, x_{8}, x_{9}, x_{10}\right) \in V\left(G_{2}\right)$ refers to the number of edges-arrows directed towards the vertex from the set $\left(x_{6}, x_{7}, x_{8}, x_{9}, x_{10}\right)$.

Therefore, the out-degree indicates how many times the GPs with numbers $1-5$ in the FRATs/FLATs groups are used. The in-degree shows how many GPs are included in the targets with numbers from 6 to 10 . Accordingly, this graph-model is a formal description of the target construction method from a set of GPs. By using it, one can obtain not 
only the Swiss/Soviet frontal targets (Khaikov, 2019), but also the flank targets.

On the basis of the two targets shown in Fig. 1 (bottom row) and their frontal images (top row of Fig. 1), it is possible to develop new geometric primitives and synthesize a full group of flanking-attacking targets. Therefore, the field of using the second graph-model has expanded.

The adjacency matrix (Fig. 6 b) is a clear and unambiguous description of the graph $\mathrm{G}_{2}$. This same matrix will correspond to both front-attacking and flank-attacking targets. This matrix has a size of $10 \times 10$. The colors of vertices $1-5$ correspond to the colors of the geometric primitives in Fig. 2, and the resulting targets 6-10 are shown in purple. Since the adjacency matrix is a sparse matrix, the single elements of the matrix are shown in light brown.

The sparsity of the adjacency matrix (Fig. 7 b) is $85 \%$, and its matrix density - $15 \%$. All nonzero-valued elements form a special upper triangular matrix with four diagonals parallel to the main diagonal. The adjacency matrix is singular.

The graph-model of the second type is indifferent to the type, but not to the number of the used GPs that make up the target. The model does not take into account the position of common boundaries in the resulting target. Thus, the $10 \times 10$ matrix is a mathematical description for both the FRATs and FLATs groups, and the shape of the targets depends on the forms of the five geometric primitives used to generate them.

\section{The third graph-model}

The third graph model (Fig. 7) uses an oriented graph in which the vertices of the graph are the GPs and edges of the graph - the existence of common borders between the GPs. Two areas in GP No. 2 (see Fig. 2 , light green designation) are considered as a coherent whole.

Two groups of targets, their decomposition to a set of GPs, and the graphs of FRATs and FLATs are presented in Fig. 7. The arrows in the forward (and reverse) directions indicate that the common borders between the GPs can be crossed in the forward and reverse directions. The designations «No. I- $\mathrm{V}$ » show the number of the graph. The colors of the GPs are identical to those in Fig. 2. Each FRAT/FLAT group includes 5 graphs with the formulas: $G 3-(I-V)=(V, E)$ : G3-I = (1, 0); G3-II = (2, 2); G3-III $=(3,6)$; G3-IV $=(4,8)$; and G3-V $=(5,10)$. The graph-model of building targets for FRATs and FLATs groups is the same. 


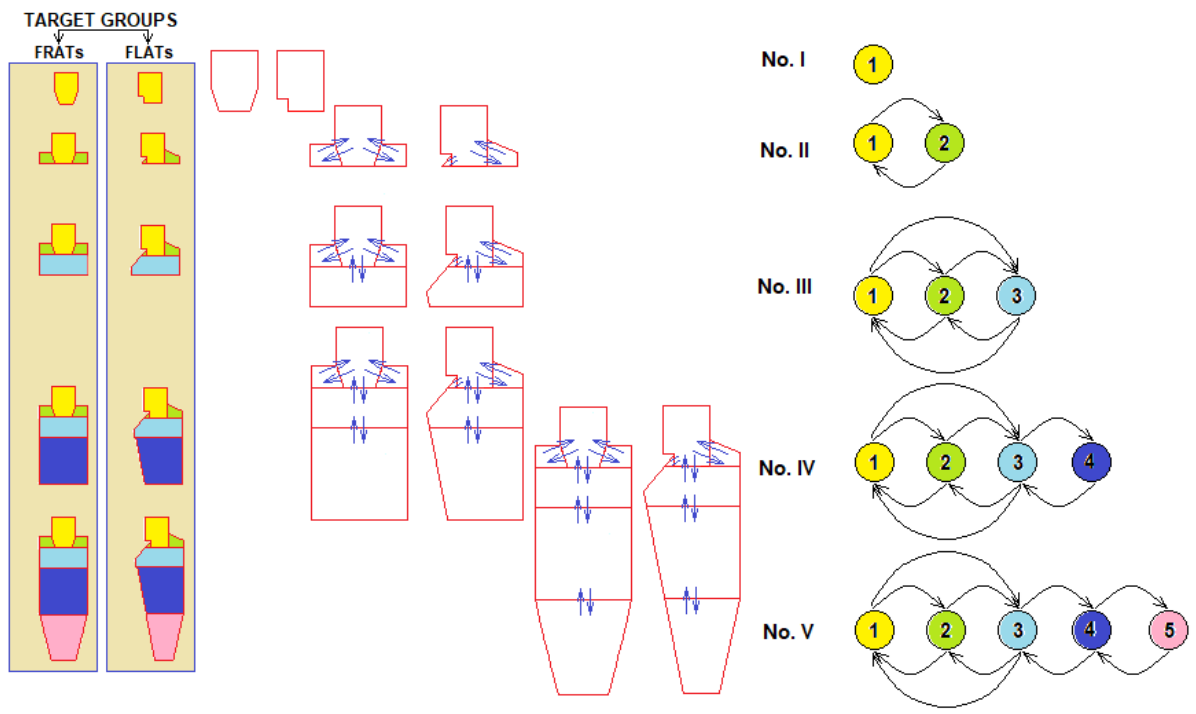

Figure 7 - The implementation of the third graph-model for five FRATs and five FLATs

Puc. 7 - Реализация третьей графр-модели для пяти фрронтальных и пяти фрлангово-атакующих стрелковых мишеней

Слика 7 - Примена трећег модела графа за пет фронталних и пет бочних мета за гађање

The indifference (non-sensitivity) of the graph to the type of geometric primitives confirmed by the use different sets of GPs, but the same graph-structure. In this case one can generate both a frontalattacking targets and a flank-attacking targets. On the left, near each of the I-V graphs, a FRAT/FLAT silhouette is represented.

Similarly to the model of the second type, the graph-model of the third type is indifferent to the used GPs, but unlike the previous, it is able to take into account the features of the common borders between the GPs (for example, their length).

\section{Conclusions}

The basis of an individual description of a target in the form of a graph is a set of vertices and edges connecting them (I model). Using additional information about the number of geometric primitives and their location in the silhouette, one can investigate the complexity of a certain target. 
The basis of the description of a set of targets is a group of geometric primitives. They describe the target either formally (II model) taking into account only the number of primitives in the target, or with additional consideration of the common boundaries between them (III model).

The combination of the I-III developed models makes it possible to describe silhouettes and their groups and to characterize the process of modifying the shape of the target inside the selected group. Knowledge of the shape modifying rules allows the synthesis of new targets.

\section{References}

Bondy, J.A., \& Murty, U.S.R. 1982. Graph theory with applications. New York: North Holland.

Boukhtouta, A., Bedrouni, A., \& Berger J. 2011. A survey of military planning systems.

[online]

Available

at:

https://www.researchgate.net/publication/228437196_

AGuitouni_A_survey_of_military_planning_systems.

Hocker, J.R. 2012. Graph theory - a management tool for the U.S. Army. BiblioScholar.

Kennedy, J.W., \& Quintas, L.V. 1988. Applications of graphs in chemistry and physics. New York: North Holland.

Khaikov, V.L. 2019. Analysis of two groups of plane infantry targets as sets of geometric primitives. Vojnotehnički glasnik/Military Technical Courier, 67(2), pp.270-287. Available at: https://doi.org/10.5937/vojtehg67-20258.

Lézoray, O., \& Grady, L. (eds.) 2012. Image processing and analysis with graphs. Theory and practice. CRC Press.

Talevski, J., \& Temjanovski, R. 2003. Application of graph theory in domain the geography and military geography. Sovremena makedonska odbrana, 8 (III). pp.77-94 (in Macedonian). Available at: http://eprints.ugd.edu.mk/3890/

Tarchishnikov, A.A. 2011. Kurs strel'b. Minsk: Belorusskiy natsional'nyy tekhnicheskiy universitet (in Russian). (In the original: Тарчишников, А.А. 2011. Курс стрельб. Минск: Белорусский национальный технический университет).

Tolk, A. 2012. Challenges of Combat Modeling and Distributed Simulation. In A. Tolk Ed., Engineering Principles of Combat Modeling and Distributed Simulation.Hoboken, NJ, USA: Wiley, pp.1-22. Available at: https://doi.org/10.1002/9781118180310.ch1.

-Wikipedia Contributors. 2012. Cibles de campagne Suisse. [online] Wikipedia. Available

at: https://fr.wikipedia.org/wiki/Fichier:Cibles_de_campagne_Suisse.png. Accessed: 03.02.2019.

Xu, J. 2003. Theory and application of graphs. Dordrecht: Kluwer Academic Publishers. 


\section{АНАЛИЗ И СИНТЕЗ СИЛУЭТОВ ФРОНТАЛЬНЫХ И ФЛАНГОВО- АТАКУЮЩИХ СТРЕЛКОВЫХ МИШЕНЕЙ С ИСПОЛЬЗОВАНИЕМ ГРАФОВ}

Вадим Л. Хайков

независимый исследователь, г. Краснодар, Российская Федерация

РУБРИКИ: 78.21.00 Военно-прикладные науки;

78.21.47 Баллистика. Теория стрельбы

ВИД СТАТЬИ: оригинальная научная статья

ЯЗЫК СТАТЬИ: английский

Резюме:

Целью данной статьи является раскрытие принципов анализа и методов синтеза фрронтальных и фрлангово-атакующих мишеней, c точки зрения графоов как математических инструментов. Основными задачами исследования являются разработка математического описания силуэтов мишени. В качестве окончательного результата были предложены три графр-модели.

Первая графь-модель характеризует структуру связей между вершинами и использует неориентированный граф. Модель показала, что усложнение силуэта мишени приводит к увеличению пути графра и сложности его внутренней структуры. Вторая графр-модель позволяет анализировать связность вершин графра. В этом случае используется ориентированный граф. В результате группа фрронтальных $u$ фрлангово-атакующих мишеней описывается одним общим графом. Модель показала свою индифрферентность к используемым графическим примитивам (ГП). Третья графовая модель позволяет анализировать общие границы между ГП. Она также индифрферентна к используемым примитивам (учитывает только длины их общей границы). Вторая модель, так же как и третья, описывает две выбранные группы мишеней одинаково. I-III модели позволяют исследователю проектировать ГП и выполнить синтез новых стрелковых мишеней. Используя ранее известные стрелковые мишени была предложена группа фрланговоатакующих мишеней и их пять ГП.

Ключевые слова: стрелковая мишень, геометрический примитив, математический граф, матрица смежности, Mathcad.

АНАЛИЗА И СИНТЕЗА СИЛУЕТА ФРОНТАЛНИХ И БОЧНИХ МЕТА ЗА ГАЂАЊЕ ПОМОЋУ ГРАФОВА

Вадим Л. Хајков

самостални истраживач, Краснодар, Руска Федерација 
ОБЛАСТ: примењена математика (балистика, теорија гађања)

ВРСТА ЧЛАНКА: оригинални научни рад

ЈЕЗИК ЧЛАНКА: енгЛесКИ

Сажетак:

У раду су представљени аналитички оквир и смернице за синтезу фронталних и бочних мета за гађање са становишта графра као математичког објекта. Крајњи резултат ове студије су три модела графра који на различите начине описују разматране мете за гађање. Први модел графра карактерише структуру веза између чворова помоћу неусмереног графра. Показао је да сложеност силуета доводи до повећања пута у графру и пораста сложености његове унутрашње структуре. Други модел графа омогућава анализу повезаности чворова графра, при чему се користи бипартитни графо који описује обе групе разматраних мета - и фронталне и бочне. Други модел је показао индиферентност према типовима коришћених геометријских фригура. Трећи модел графра развијен је за анализу заједничких страница суседних геометријских фигура помоћу бипартитног графа. И он је индиферентан према типовима коришћених геометријских фригура, али узима у обзир дужину заједничких страница. Трећи модел на исти начин описује групе фронталних и бочних мета за гађање. Помоћу ових модела могуће је пројектовати основне геометријске фигуре и синтетизовати нове мете. Представљена је целокупна група бочних мета за гађање која се састоји од пет силуета и њихових основних геомеријских фигура.

Кључне речи: мета за гађање, основна геометријска фригура, графр, матрица повезаности, Mathcad.

Paper received on / Дата получения работы / Датум пријема чланка: 16.05.2019.

Manuscript corrections submitted on / Дата получения исправленной версии работы / Датум достављања исправки рукописа: 11.06.2015.

Paper accepted for publishing on / Дата окончательного согласования работы / Датум коначног прихватања чланка за објављивање: 13.06.2019

(C) 2019 The Author. Published by Vojnotehnički glasnik / Military Technical Courier (www.vtg.mod.gov.rs, втг.мо.упр.срб). This article is an open access article distributed under the terms and conditions of the Creative Commons Attribution license (http://creativecommons.org/licenses/by/3.0/rs/).

() 2019 Автор. Опубликовано в «Военно-технический вестник / Vojnotehnički glasnik / Military Technical Courier» (www.vtg.mod.gov.rs, втг.мо.упр.срб). Данная статья в открытом доступе и распространяется в соответствии с лицензией «Creative Commons» (http://creativecommons.org/licenses/by/3.0/rs/).

( 2019 Аутор. Објавио Војнотехнички гласник / Vojnotehnički glasnik / Military Technical Courier (www.vtg.mod.gov.rs, Втг.мо.упр.срб). Ово је чланак отвореног приступа и дистрибуира се у складу са Creative Commons licencom (http://creativecommons.org/licenses/by/3.0/rs/). 